\title{
New allele at cholinesterase locus 1
}

\section{PHILIP J. GARRY, ${ }^{1,2}$ ALBERT A. DIETZ, ${ }^{3}$ TINA LUBRANO, ${ }^{3}$ PATRICIA C. FORD, ${ }^{1}$ KAREN JAMES, ${ }^{4}$ and HERBERT M. RUBINSTEIN ${ }^{3}$}

\begin{abstract}
Summary. A family (H-J pedigree) segregating for the A and $\mathrm{F}$ alleles at cholinesterase locus 1 is described. Apparent anomalous results led to the recognition of a new allele $\left(E_{1}{ }^{j}\right)$ also segregating in the family. The data are consistent with the hypothesis that the $E_{1}{ }^{j}$ causes reduction of 'usual' $\left(E_{1}{ }^{u}\right)$ molecules by about $66 \%$. Whether this is because of retarded synthesis or accelerated degradation of serum cholinesterase remains to be determined.
\end{abstract}

Well-attested alleles at serum cholinesterase (E.C.3.1.1.8) locus 1 are the usual $\left(\mathrm{E}_{1}{ }^{\mathrm{u}}\right)$ gene, the atypical or dibucaine-resistant $\left(\mathrm{E}_{1}{ }^{\mathrm{a}}\right)$ gene, the fluoride-resistant $\left(\mathrm{E}_{1}{ }^{\mathrm{f}}\right)$ gene, and the silent $\left(\mathrm{E}_{1}{ }^{\mathrm{s}}\right)$ gene, the last one existing in several different forms (Rubinstein et al, 1970; Lubin et al, 1973). A family in which several members have extremely high serum cholinesterase levels has been reported and the responsible gene has been termed $\mathrm{E}$ Cynthiana but it is not yet known if this gene is active at locus 1 or locus 2 (Neitlich, 1966; Yoshida and Motulsky, 1969). Whittaker (1968a, b) postulated the existence of other alleles at locus 1 detectable by abnormal inhibitions with $\mathrm{NaCl}$ and $n$-butanol, but these observations remain unconfirmed. Finally, Lehmann et al (1960) have described a family whose cholinesterase activities and inhibitions cannot be explained by the known alleles at locus 1 .

We report here a pedigree (H-J) which clearly proves the existence of another allele at locus 1 . In this pedigree the allele, which we term $\mathbf{E}_{1}{ }^{1}$, interacts with the atypical and fluoride alleles; the resultant double heterozygotes give characteristic results by a variety of tests and can be distinguished from all other known phenotypes in this system.

Received 13 January 1975.

1 Department of Pediatrics, Children's Hospital, Columbus, OH 43205, USA.

2 Present address: Clinical Nutrition Laboratory, University of Mexico, Albuquerque, NM 87131, USA.

${ }^{3}$ Research and Medical Services, Veterans Administrative Hospital, Hines, IL 60141 and Departments of Medicine and Biochemistry, Loyola University of Chicago, Stritch School of Medicine, Maywood, IL 60153, USA.

4 Department of Pathology, Ohio State University School of Medicine, Columbus, OH 43210, USA.
By genetic analysis the pedigree contains three examples of the heterozygote $E_{1}{ }^{n} E_{1}{ }^{j}$ but this phenotype cannot be distinguished by testing. No example of $\mathrm{E}_{1}{ }^{j} \mathrm{E}_{1}{ }^{\mathrm{j}}$ occurs in the family. The existence of the $\mathbf{E}_{1}{ }^{j}$ allele may offer an explanation for the family reported by Lehmann et al (1960).

\section{Materials and methods}

The index case, III.20 (Fig. 1), was found to have a lowered serum cholinesterase activity and was refused employment which involved exposure to anticholinesterase compounds. Sera from this subject and other members of the H-J pedigree were stored at 4 or $-20^{\circ} \mathrm{C}$ until tested. All sera were tested in two laboratories.

\section{Laboratory A (P.J.G., P.C.F., and K.J.)}

The automated methods used for determination of the serum cholinesterase phenotypes in laboratory $A$ have been reported (Garry, 1971; Garry, Owen, and Lubin, 1972). Butyrylthiocholine, $2 \mathrm{mmol} / \mathrm{l}$, was used as substrate with fluoride as an inhibitor in both $0.05 \mathrm{~mol}$ phosphate and Tris buffer systems at $25^{\circ} \mathrm{C}$. The results for the serum cholinesterase phenotypes thus far determined are given in Table I.

\section{Laboratory B (T.L., A.A.D., and H.M.R.)}

The methods employed in laboratory $B$ have also been reported (Dietz et al, 1972; Dietz, Rubinstein, and Lubrano, 1973). The substrate was propionylthiocholine with dibucaine and fluoride as inhibitors in phosphate buffer at $37^{\circ} \mathrm{C}$. In the present study, butyrylthiocholine was also used as substrate. In addition, $\mathrm{NaCl}$ was used as an inhibitor, with the final concentration of $\mathrm{NaCl} 0.5 \mathrm{~mol} / \mathrm{l}$. Table II gives the results for the serum cholinesterase phenotypes previously studied. The presence or absence of $\mathrm{C} 5+$ (cholinesterase locus 2) was determined by the acrylamide electrophoretic method of Simpson (1972). 
I
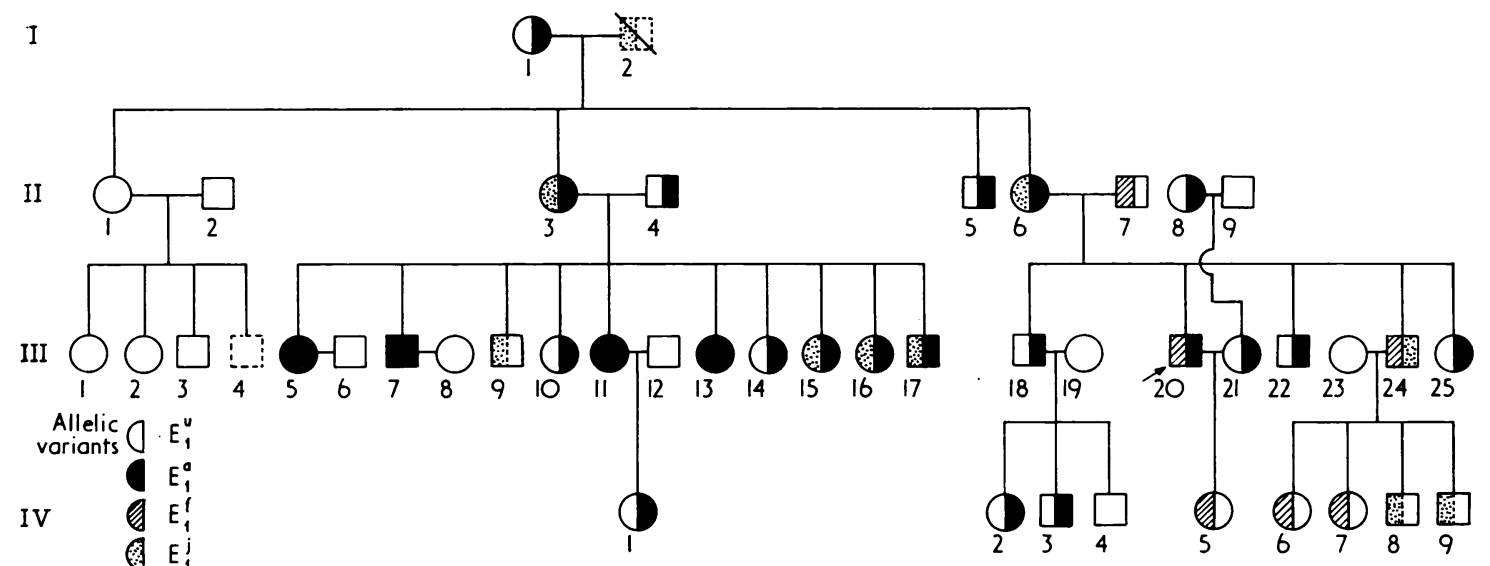

FIG. 1. Pedigree of the family.

TABLE I

LABORATORY A: RESULTS FOR VARIOUS SERUM PHENOTYPES

\begin{tabular}{|c|c|c|c|c|c|}
\hline \multicolumn{2}{|c|}{ Nomenclature } & \multirow{2}{*}{ Activity* } & \multirow{2}{*}{$\begin{array}{c}\text { Phosphate } \\
\text { Inhibition }\left({ }^{\circ}\right)\end{array}$} & \multicolumn{2}{|c|}{ Fluoride Inhibition ( $\%$ ) } \\
\hline Phenotype & Genotype & & & Tris Buffer & Phosphate Buffer \\
\hline $\begin{array}{l}\text { UA } \\
\text { AA } \\
\text { UF }\end{array}$ & $\begin{array}{l}E_{1}{ }^{u} E_{1} u \\
E_{1} u E_{1}^{a} \\
E_{1}^{a} E_{1}^{a} \\
E_{1}^{u} E_{1}^{f} \\
E_{1} E_{1} E^{f}\end{array}$ & $\begin{array}{l}3.93 \pm 1.65 \dagger \ddagger \\
2.97 \pm 1.60 \\
2.05 \pm 1.20 \\
3.60 \pm 1.60 \\
2.00\end{array}$ & $\begin{array}{c}0 \\
15 \pm 5 t \\
42 \pm 4 \\
0 \\
0\end{array}$ & $\begin{array}{l}73 \pm 2.0 \dagger \\
71 \pm 4.0 \\
62 \pm 4.0 \\
65 \pm 4.0 \\
54\end{array}$ & $\begin{array}{l}45 \pm 3.0 t \\
50 \pm 4.0 \\
64 \pm 6.05 \\
38 \pm 4.0 \\
29\end{array}$ \\
\hline
\end{tabular}

* Activity is expressed as $\mathrm{IU} / \mathrm{min}$ per $\mathrm{ml}$ at $25^{\circ} \mathrm{C}$.

+ \pm 2 standard deviations.

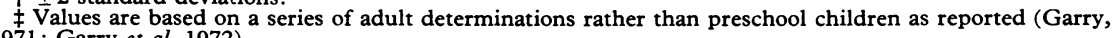
1971; Garry et al, 1972).

$\int$ This value differs from the value previously published (Garry et al, 1972) because inhibition values with fluoride in phosphate buffer are highly dependent on temperature and concentration of sodium fluoride. It is not always possible to know the exact concentration of $\mathrm{NaF}$ in the automated system. However, the various serum cholinesterase variants fall into specific areas when $\mathrm{NaF}$ inhibition values determined in phosphate buffer are plotted against $\mathrm{NaF}$ inhibition values determined in Tris buffer (Fig. 2).

TABLE II

LABORATORY B: RESULTS FOR VARIOUS SERUM CHOLINESTERASE PHENOTYPES

\begin{tabular}{|c|c|c|c|c|c|c|}
\hline \multicolumn{2}{|c|}{ Nomenclature } & \multirow{2}{*}{$\begin{array}{l}\text { Activity* } \\
\mathrm{U} \pm 1 \text { SD }\end{array}$} & \multirow{2}{*}{ PTCI/BTCI } & \multicolumn{3}{|c|}{ Inhibition, $\% \pm 1 \mathrm{SD}$} \\
\hline Phenotype & Genotype & & & Dibucaine & Fluoride & $\mathrm{NaCl}$ \\
\hline $\begin{array}{l}\text { U } \\
\text { A } \\
\text { AS } \\
\text { S }_{1} \\
\text { S }_{2} \\
\text { F } \\
\text { AF } \\
\text { FS } \\
\text { UA } \\
\text { UF } \\
\text { US }\end{array}$ & 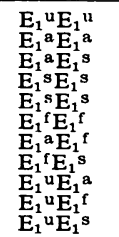 & $\begin{array}{l}8.44 \pm 1.78 \\
1.90 \pm 0.61 \\
1.30 \pm 0.37 \\
0.03 \pm 0.01 \\
0.18 \pm 0.05 \\
3.57 \\
3.65 \pm 0.47 \\
3.47 \\
5.84 \pm 1.76 \\
5.99 \pm 1.26 \\
4.61 \pm 0.57\end{array}$ & $\begin{array}{l}0.90 \\
1.16 \pm 0.02 \\
1.13 \pm 0.03\end{array}$ & $\begin{array}{r}83.6 \pm 1.3 \\
19.9 \pm 2.7 \\
20.7 \pm 4.1 \\
5.3 \pm 4.3 \\
67.6 \pm 4.3 \\
71.8 \\
60.2 \pm 3.1 \\
76.7 \pm 3.1 \\
72.7 \pm 3.1 \\
79.8 \pm 1.2 \\
84.4 \pm 0.8\end{array}$ & $\begin{array}{l}79.7 \pm 1.2 \\
84.0 \pm 1.8 \\
82.3 \pm 3.4 \\
35.7 \pm 6.1 \\
67.7 \pm 1.7 \\
53.6 \\
68.3 \pm 1.0 \\
64.9 \\
80.0 \pm 1.6 \\
73.0 \pm 1.7 \\
79.3 \pm 1.4\end{array}$ & $\begin{array}{l}47.5 \\
43.1 \pm 1.1 \\
41.0 \pm 1.1\end{array}$ \\
\hline
\end{tabular}

* Activity is expressed in IU/min per $\mathrm{ml}$ at $37^{\circ} \mathrm{C}$ with PTCI as substrate.

PTCI, propionylthiocholine iodide; BTCI, butyrylthiocholine iodide. 
TABLE III

RESULTS IN H-J FAMILY

\begin{tabular}{|c|c|c|c|c|c|c|c|c|c|}
\hline \multirow{3}{*}{$\begin{array}{c}\text { Pedigree } \\
\text { No }\end{array}$} & \multirow{3}{*}{$\begin{array}{l}\text { Presumed } \\
\text { Genotype }\end{array}$} & \multicolumn{4}{|c|}{ Laboratory B } & \multicolumn{4}{|c|}{ Laboratory A } \\
\hline & & \multirow{2}{*}{$\begin{array}{l}\text { Activity } \\
\text { PTCI }\end{array}$} & \multirow{2}{*}{$\underset{\text { PTCI/BTCI }}{\text { Ratio of }}$} & \multicolumn{2}{|c|}{ Inhibition (\%) } & \multirow{2}{*}{$\begin{array}{l}\text { Activity } \\
\text { BTCI }\end{array}$} & \multirow{2}{*}{$\begin{array}{l}\text { Phosphate } \\
\text { Inhibition }\end{array}$} & \multicolumn{2}{|c|}{ Fluoride Inhibition (\%) } \\
\hline & & & & Dibucaine & Fluoride & & & Tris Buffer & Phos. Buffer \\
\hline $\begin{array}{r}\text { I.1 } \\
\text { II.1 } \\
2 \\
3 \\
4 \\
5 \\
6 \\
7 \\
8 \\
9 \\
\text { III.1 } \\
2 \\
3 \\
5 \\
6 \\
7 \\
8 \\
9 \\
10 \\
11 \\
12 \\
13 \\
14 \\
15 \\
16 \\
17 \\
18 \\
19 \\
20 \\
21 \\
22 \\
23 \\
24 \\
25 \\
\text { IV.1 } \\
2 \\
3 \\
4 \\
5\end{array}$ & 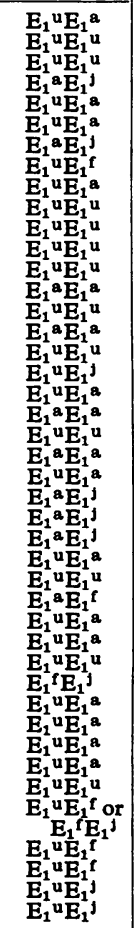 & \begin{tabular}{r|}
4.25 \\
8.79 \\
6.38 \\
2.52 \\
4.56 \\
6.50 \\
1.33 \\
9.22 \\
5.50 \\
7.24 \\
6.82 \\
7.78 \\
8.24 \\
1.00 \\
11.98 \\
2.14 \\
6.07 \\
4.53 \\
3.68 \\
1.66 \\
7.35 \\
1.21 \\
3.60 \\
1.72 \\
1.90 \\
2.20 \\
5.47 \\
8.09 \\
3.32 \\
1.77 \\
5.24 \\
5.58 \\
3.99 \\
5.15 \\
4.38 \\
6.03 \\
6.57 \\
9.00 \\
\\
5.50 \\
6.10 \\
6.15 \\
4.91 \\
4.78
\end{tabular} & $\begin{array}{l}1.17 \\
1.29 \\
1.32 \\
1.02 \\
1.19 \\
1.13 \\
0.97 \\
1.12 \\
\\
1.29 \\
1.26 \\
1.24 \\
0.85 \\
1.29 \\
0.83 \\
1.30 \\
1.42 \\
1.13 \\
0.86 \\
1.27 \\
0.98 \\
1.11 \\
1.07 \\
1.01 \\
1.03 \\
1.11 \\
1.23 \\
0.89 \\
1.08 \\
1.09 \\
1.21 \\
0.98 \\
1.19 \\
1.15 \\
1.22 \\
1.11 \\
1.28 \\
1.09 \\
1.14 \\
1.11 \\
1.24 \\
1.26\end{array}$ & $\begin{array}{l}76.5 \\
84.8 \\
83.4 \\
53.4 \\
73.9 \\
74.4 \\
54.2 \\
78.3 \\
75.4 \\
83.5 \\
84.9 \\
84.9 \\
83.6 \\
22.6 \\
84.8 \\
16.8 \\
86.0 \\
84.4 \\
71.2 \\
20.4 \\
83.8 \\
21.9 \\
68.9 \\
58.3 \\
59.7 \\
59.2 \\
72.4 \\
85.3 \\
55.8 \\
70.0 \\
72.9 \\
83.5 \\
76.9 \\
72.6 \\
73.2 \\
72.9 \\
73.6 \\
85.9 \\
78.1 \\
78.0 \\
80.2 \\
81.2 \\
85.4 \\
\end{array}$ & $\begin{array}{l}80.4 \\
81.1 \\
80.0 \\
83.4 \\
78.7 \\
81.2 \\
83.8 \\
73.7 \\
81.7 \\
78.2 \\
80.8 \\
80.3 \\
80.7 \\
83.2 \\
81.1 \\
83.8 \\
81.4 \\
80.5 \\
82.0 \\
84.1 \\
80.2 \\
85.0 \\
83.2 \\
79.1 \\
81.4 \\
82.3 \\
81.2 \\
78.7 \\
69.2 \\
80.9 \\
81.3 \\
79.6 \\
68.2 \\
81.3 \\
79.9 \\
79.8 \\
84.1 \\
80.6 \\
71.4 \\
73.7 \\
70.6 \\
77.9 \\
80.0\end{array}$ & $\begin{array}{l}2.78 \\
4.87 \\
3.64 \\
2.17 \\
3.47 \\
4.31 \\
1.25 \\
5.40 \\
\\
3.70 \\
4.35 \\
4.69 \\
1.38 \\
6.38 \\
2.78 \\
3.47 \\
2.59 \\
2.53 \\
2.01 \\
4.03 \\
1.34 \\
2.68 \\
1.34 \\
1.52 \\
1.80 \\
3.64 \\
4.67 \\
2.89 \\
1.45 \\
3.78 \\
3.11 \\
2.74 \\
3.39 \\
3.31 \\
4.20 \\
4.12 \\
5.19 \\
3.87 \\
4.10 \\
3.93 \\
3.05 \\
2.76\end{array}$ & $\begin{array}{c}12.3 \\
0 \\
0 \\
26.5 \\
9.0 \\
11.3 \\
29.1 \\
0 \\
\\
0 \\
0 \\
0 \\
38.2 \\
0 \\
37.9 \\
0 \\
0 \\
12.3 \\
37.4 \\
0 \\
39.5 \\
16.1 \\
20.8 \\
23.2 \\
25.0 \\
13.0 \\
0 \\
18.9 \\
15.2 \\
13.4 \\
0 \\
0 \\
11.8 \\
10.9 \\
12.7 \\
11.0 \\
0 \\
0 \\
0 \\
0 \\
0 \\
0 \\
0\end{array}$ & $\begin{array}{l}67.0 \\
71.7 \\
72.6 \\
66.8 \\
70.0 \\
68.3 \\
67.4 \\
65.6 \\
\\
\\
72.3 \\
71.9 \\
71.8 \\
63.6 \\
71.6 \\
63.0 \\
72.9 \\
72.2 \\
69.6 \\
64.1 \\
71.6 \\
65.3 \\
68.3 \\
67.9 \\
66.6 \\
68.3 \\
69.9 \\
72.1 \\
56.5 \\
70.1 \\
70.1 \\
72.3 \\
59.4 \\
70.3 \\
68.7 \\
69.7 \\
68.9 \\
72.0 \\
59.6 \\
65.1 \\
63.8 \\
73.4 \\
72.6\end{array}$ & $\begin{array}{l}51.0 \\
47.4 \\
46.7 \\
58.4 \\
51.9 \\
54.5 \\
59.0 \\
40.5 \\
\\
46.1 \\
45.9 \\
45.7 \\
68.6 \\
45.0 \\
68.6 \\
47.5 \\
46.4 \\
52.9 \\
67.9 \\
45.9 \\
65.8 \\
53.3 \\
56.3 \\
55.4 \\
57.8 \\
52.0 \\
45.8 \\
43.3 \\
52.9 \\
52.2 \\
47.1 \\
35.1 \\
53.2 \\
52.0 \\
51.8 \\
52.9 \\
45.7 \\
33.8 \\
40.7 \\
39.1 \\
47.0 \\
47.0\end{array}$ \\
\hline
\end{tabular}

Abbreviations as for Table II.

\section{Results and discussion}

The results for each individual tested in the H-J pedigree are set out in Table III. Comparison of these data with those given in Tables I and II reveals that some of the individuals (II. 3,6 ; III.15, 16,17 , and 24) do not fall into any previously known phenotype. These results can be explained by postulating a new allele $\left(E_{1}{ }^{j}\right)$ which must have stemmed from I.2. Subjects II.3 and 6; III.15, 16 , and 17 are thus interpreted as genotype $E_{1}{ }^{a} E_{1}{ }^{1}$. Subject III.24 can be assigned to genotype $\mathrm{E}_{1}{ }^{\mathrm{T}} \mathrm{E}_{1}{ }^{1}$ both by genetic analysis and by abnormal assay values. On purely genetic grounds three individuals (III.9; IV.8 and 9) must have constitution $E_{1}{ }^{~} E_{1}{ }^{1}$. Though they demonstrate somewhat lowered enzyme activity, there is nothing in the analytical results which clearly distinguishes them from $E_{1}{ }^{u} E_{1}{ }^{u}$. Fig. 1 shows the pedigree with presumed genotypes, and Fig. 2 and 3 clarify the identification of the new phenotypes with respect to previously known ones.

There is some uncertainty about several of the presumed genotypes. III.20 is clearly $\mathrm{E}_{1}{ }^{\mathrm{a}} \mathrm{E}_{1}{ }^{\mathrm{f}}$. In both laboratories, serum of his wife, III.21, shows inhibitions typical of $E_{1}{ }^{4} E_{1}{ }^{a}$ but with considerably lowered enzyme activity. Whether this reduction in cholinesterase activity is caused by intercurrent disease or medication is not known. The parents of III.21 (II.8 and 9) are $\mathrm{E}_{1}{ }^{\mathrm{u}} \mathrm{E}_{1}{ }^{\mathrm{u}}$ and $\mathrm{E}_{1}{ }^{\mathrm{u}} \mathrm{E}_{1}{ }^{\mathrm{a}}$, as determined in laboratory $B$. The daughter of III.21 shows somewhat different findings in each laboratory. In laboratory $B$, her serum gives results consistent with constitution $\mathrm{E}_{1}{ }^{\mathrm{u}} \mathrm{E}_{1}{ }^{\mathrm{f}}$ which agrees with the genetic assignment of her parents and grandparents. On the other hand, in laboratory A the serum of IV.5 gives results similar to that of III.24 despite the apparent absence of the $\mathrm{E}_{1}{ }^{\mathrm{j}}$ allele in both parents. 


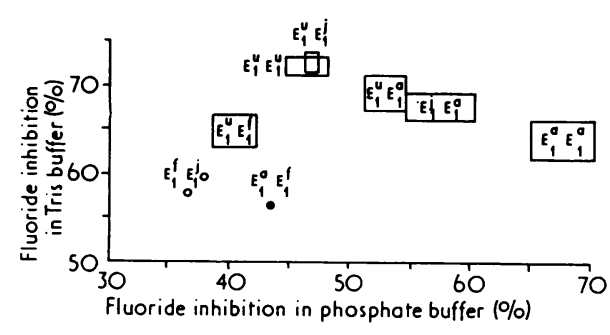

FIG. 2. Distribution of the cholinesterase variants in the family as determined in laboratory $A$. The identification of each phenotype is based on the relative inhibition by fluoride in both Tris and phosphate buffer.

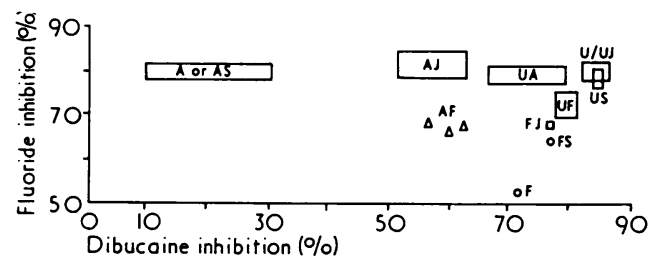

FIG. 3. Distribution of the known cholinesterase phenotypes as identified in laboratory B. Each variant is judged from its relative inhibition by fluoride and dibucaine in phosphate buffer.

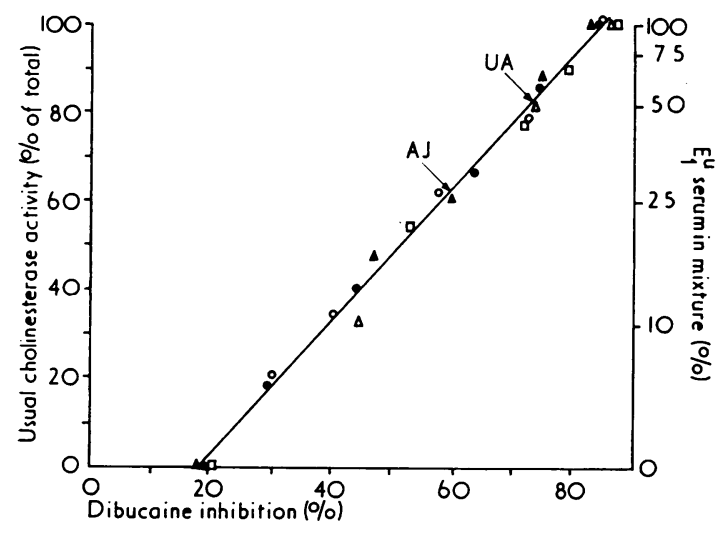

FIG. 4. Dibucaine inhibition of mixtures of $E_{1}{ }^{u} E_{1} u$ and $E_{1}{ }^{a} E_{1} a$ sera. Different symbols represent mixtures of different sera. The left ordinate represents the percentage of total activity due to $E_{1}{ }^{u} E_{1} u$ as estimated from the activities of the unmixed sera. The right ordinate gives the percentage of $E_{1}{ }^{u} E_{1} u$ serum when starting with hypothetical $E_{1}{ }^{u} E_{1}{ }^{u}$ and $E_{1}{ }^{a} E_{1}{ }^{a}$ sera of average activities (Table II).

Chloride inhibitions were included in our study since Whittaker (1968b) had suggested that new phenotypes may be discovered in this way. In the $\mathrm{H}-\mathrm{J}$ family the results of chloride inhibition were not helpful and are, therefore, not given in the Table. The new phenotypes were more readily distinguished by inhibitions with dibucaine and fluoride.
Acrylamide gel electrophoresis of all members of the family showed the $\mathrm{C} 5+$ cholinesterase allele of locus 2 present only in II.7 and two of his children, III.22 and III.25. The remainder of the subjects were considered to be $\mathrm{C} 5-$.

The $\mathrm{E}_{1}{ }^{\mathrm{a}}$ and $\mathrm{E}_{1}{ }^{\mathrm{f}}$ alleles give rise to qualitatively abnormal enzyme molecules as revealed by inhibition tests with dibucaine and fluoride, respectively. The $\mathrm{E}_{1}{ }^{\mathrm{j}}$ allele can, however, be interpreted as resulting in reduced numbers of circulating usual $\left(E_{1}{ }^{u}\right)$ molecules. This could be because of reduced synthesis or accelerated degradation of the $\mathrm{E}_{1}{ }^{\mathrm{u}}$ molecules. In the described pedigree the individuals assigned genotype $\mathrm{E}_{1}{ }^{\mathrm{a}} \mathrm{E}_{1}{ }^{\mathrm{j}}$ have dibucaine inhibition values between $\mathrm{E}_{1}{ }^{\mathrm{u}} \mathrm{E}_{1}{ }^{\mathrm{a}}$ and $\mathrm{E}_{1}{ }^{\mathrm{a}} \mathrm{E}_{1}{ }^{\mathrm{a}}$. This is the expected result if the $E_{1}{ }^{j}$ allele causes reduced numbers of circulating $\mathrm{E}_{1}{ }^{\mathrm{u}}$ molecules. Though the changes are more modest, the fact that III.24 $\left(\mathrm{E}_{1}{ }^{\mathrm{T}} \mathrm{E}_{1}{ }^{j}\right)$ has fluoride inhibitions between $E_{1}{ }^{u} E_{1}{ }^{\mathrm{f}}$ and $\mathrm{E}_{1}{ }^{\mathrm{r}} \mathrm{E}_{1}{ }^{\mathrm{f}}$ is also consistent with this hypothesis.

According to Kalow and Staron (1957), the activity and dibucaine inhibition of average $E_{1}{ }^{u} E_{1}{ }^{a}$ sera represent an approximate 50:50 mixture of average $E_{1}{ }^{u} E_{1}{ }^{u}$ and $E_{1}{ }^{a} E_{1}{ }^{a}$ sera. By their mode of calculation, the five $\mathrm{E}_{1}{ }^{a} \mathrm{E}_{1}{ }^{j}$ sera in the present pedigree correspond roughly to a 25:75 mixture of average $\mathrm{E}_{1}{ }^{\mathrm{u}} \mathrm{E}_{1}{ }^{\mathrm{u}}$ and $\mathrm{E}_{1}{ }^{\mathrm{a}} \mathrm{E}_{1}{ }^{a}$ sera.

The same approximation can also be found by mixing an average $\mathrm{E}_{1}{ }^{\mathrm{u}} \mathrm{E}_{1}{ }^{\mathrm{u}}$ serum with an average $\mathrm{E}_{1}{ }^{a} \mathrm{E}_{1}{ }^{a}$ serum in varying proportions and measuring the dibucaine inhibition of the mixtures. Fig. 4 shows such an experiment. The dibucaine inhibition of average $E_{1}{ }^{u} E_{1}{ }^{a}$ sera corresponds to a 50:50 mixture and the average dibucaine inhibition of the five $\mathrm{E}_{1}{ }^{\mathrm{a}} \mathrm{E}_{1}{ }^{\mathrm{j}}$ sera from the $\mathrm{H}-\mathrm{J}$ family to an approximate 25:75 ratio of $\mathrm{E}_{1}{ }^{\mathrm{u}}$ and $\mathrm{E}_{1}{ }^{\mathrm{a}}$ molecules.

Based on these approximations, one may calculate that the $\mathrm{E}_{1}{ }^{\mathrm{j}}$ allele causes about $66 \%$ reduction of $\mathrm{E}_{1}{ }^{\mathrm{u}}$ molecules (Rubinstein et al, 1976). This is in contrast to the $\mathrm{E}_{1} \mathrm{~s}$ gene which produces a 97 to $100 \%$ reduction of $\mathrm{E}_{1}{ }^{\mathrm{u}}$ molecules (Rubinstein et al, 1970).

The existence of the $\mathrm{E}_{1}{ }^{\mathrm{j}}$ allele would satisfactorily explain the unusual pattern of cholinesterase activities and dibucaine inhibitions in the family described by Lehmann et al (1960). In that family I.1 can be interpreted as $\mathrm{E}_{1}{ }^{\mathrm{u}} \mathrm{E}_{1}{ }^{\mathrm{a}}$; $\mathrm{I} .2$ as $\mathrm{E}_{1}{ }^{\mathrm{u}} \mathrm{E}_{1}{ }^{\mathrm{j}}$; II.1, 2, 3, 4, 6 as $\mathrm{E}_{1}{ }^{\mathrm{a}} \mathrm{E}_{1}{ }^{\mathrm{j}}$; and II.5 as either $\mathrm{E}_{1}{ }^{\mathrm{u}} \mathrm{E}_{1}{ }^{\mathrm{u}}$ or $E_{1}{ }^{u} E_{1}{ }^{j}$. Their explanation of the results is similar to our own; they suggest the existence of a rare gene which suppresses the 'usual' form of enzyme relative to the atypical form.

At present there is no direct way of diagnosing the $\mathrm{E}_{1}{ }^{\mathrm{u}} \mathrm{E}_{1}{ }^{\mathrm{j}}$ constitution. Hence the $\mathrm{E}_{1}{ }^{\mathrm{j}}$ allele can 
only be recognized by seemingly anomalous results in families segregating for other variants at locus 1. Determination of gene frequency can, therefore, only be indirect. The recognition of only two such families to date suggests that it is a very rare gene.

In view of the relatively low dibucaine inhibition and enzyme activity, it is reasonable to assume that an $E_{1}{ }^{a} E_{1}{ }^{j}$ individual is subject to prolonged succinylcholine-induced apnoea. Though our case was not found in this way, the family of Lehmann et al (1960) was. Whether individuals of $\mathrm{E}_{1}{ }^{\mathrm{f}} \mathrm{E}_{1}{ }^{\mathrm{j}}$ constitution are prone to prolonged apnoea remains to be determined.

No $E_{1}{ }^{j} E_{1}{ }^{j}$ or $E_{1}{ }^{s} E_{1}{ }^{j}$ subjects have yet been identified. Since both such types can be expected to have 'usual' enzyme molecules in reduced numbers, the analytical results should be those of normal inhibitions and low cholinesterase activity. There is nothing specific in this pattern and it cannot be distinguished from that of $E_{1}{ }^{u} E_{1}{ }^{u}$ individuals whose cholinesterase activity is reduced because of disease or anticholinesterase medication. Therefore $E_{1}{ }^{j} E_{1}{ }^{j}$ and $E_{1}{ }^{s} E_{1}^{j}$ individuals can only be clearly defined on genetic grounds; whether or not they are vulnerable to prolonged succinylcholineinduced apnoea cannot be predicted with certainty.

\section{REFERENCES}

Dietz, A. A., Rubinstein, H. M., and Lubrano, T. (1973). Colorimetric determination of serum cholinesterase and its genetic variants by the propionylthiocholinedithiobis (nitrobenzoic acid) procedure. Clinical Chemistry, 19, 1309-1313.

Dietz, A. A., Rubinstein, H. M., Lubrano, T., and Hodges, L. K. (1972). Improved method for the differentiation of cholinesterase variants. American fournal of Human Genetics, 24, 58-64.

Garry, P. J. (1971). A manual and automated procedure for measuring serum cholinesterase activity and identifying enzyme variants. Clinical Chemistry, 17, 192-198.

Garry, P. J., Owen, G. M., and Lubin, A. H. (1972). Identification of serum cholinesterase fluoride variants by differential inhibition in Tris and phosphate buffers. Clinical Chemistry, 18, 105-109.

Kalow, W. and Staron, N. (1957). Distribution and inheritance of atypical forms of human serum cholinesterase, as indicated by dibucaine numbers. Canadian fournal of Biochemistry and Physiology, 35, 1305-1317.

Lehmann, H., Silk, E., Harris, H., and Whittaker, M. (1960). New pseudocholinesterase phenotype? Acta Genetica et Statistica Medica, 10, 241-246.

Lubin, A. H., Garry, P. J., Owen, G. M., Prince, L. C., and Dietz, A. A. (1973). Further variation of the 'silent' cholinesterase gene. Biochemical Medicine, 8, 160-169.

Neitlich, H. W. (1966). Increased plasma cholinesterase activity and succinylcholine resistance: a genetic variant. Fournal of Clinical Investigation, 45, 380-387.

Rubinstein, H. M., Dietz, A. A., Hodges, L. K., Lubrano, T., and Czebotar, V. (1970). Silent cholinesterase gene: variations in the properties of serum enzyme in apparent homozygotes. Fournal of Clinical Investigation, 49, 479-486.

Rubinstein, H. M., Dietz, A. A., Lubrano, T., and Garry, P. J. (1976). $E_{1}^{j}, A$ quantitative variant at cholinesterase locus 1 Fournal of Medical Genetics, 13, 43-45.

Simpson, N. E. (1972). Polyacrylamide electrophoresis used for the detection of $\mathrm{C} 5+$ cholinesterase in Canadian Caucasians, Indians, and Eskimos. American fournal of Human Genetics, 24, 317-320.

Whittaker, M. (1968a). Differential inhibition of human serum cholinesterase with $n$-butyl alcohol: recognition of new phenotypes. Acta Genetica et Statistica Medica, 18, 335-340.

Whittaker, M. (1968b). The pseudocholinesterase variants. Differentiation by means of sodium chloride. Acta Genetica et Statistica Medica, 18, 556-562.

Yoshida, A. and Motulsky, A. G. (1969). A pseudocholinesterase variant (E Cynthiana) associated with elevated plasma enzyme activity. American fournal of Human Genetics, 21, 486-498. 